\title{
Epidemiological Status and Vector Identification of Bovine Trypanosomiosis in Didesa District of Oromia Regional State, Ethiopia
}

\author{
Gamechu Fayisa ${ }^{2}$, Aynalem Mandefro ${ }^{1}$, Birhanu Hailu ${ }^{1,}$, , Gemechu Chala ${ }^{2}$, Gezahegn Alemayehu ${ }^{1}$ \\ ${ }^{1}$ College of Veterinary Medicine, Samara University, Samara, Ethiopia \\ ${ }^{2}$ School of Veterinary Medicine, Hawassa University, Hawassa, Ethiopia
}

Email address:

birhailu2002@gmail.com (B. Hailu)

\section{To cite this article:}

Gamechu Fayisa, Aynalem Mandefro, Birhanu Hailu, Gemechu Chala, Gezahegn Alemayehu. Epidemiological Status and Vector Identification of Bovine Trypanosomiosis in Didesa District of Oromia Regional State, Ethiopia. International Journal of Nutrition and Food Sciences. Vol. 4, No. 3, 2015, pp. 373-380. doi: 10.11648/j.ijnfs.20150403.25

\begin{abstract}
A cross sectional study was conducted in Didesa district of Oromia Regional State from November 2013 to June 2014 to determine the prevalence of trypanosomosis and tsetse density. Simple random sampling was used to select 556 cattle from the purposively selected four PAs for collection of blood sample. Buffy coat technique was used to determine prevalence of bovine trypansomiosis in the study area and trap was deployed for collection of tsetse flies. Blood sample was examined and it was found that $27(4.86 \%)$ were parasitic positive. The prevalence was insignificant $(\mathrm{P}>0.05)$ in sex group, age, body condition score and between peasant association. But PCV between parasitemic and aparasitaemic is significant ( $\mathrm{p}<0.05)$.In this study the most common trypanosome species identified were T. congolense $(17 / 27,62.96 \%)$ followed by T. vivax $(9 / 27$, $33.33 \%$ and mixed $\mathrm{T}$. vivax and $\mathrm{T}$. congolense $(1 / 27,3.70 \%)$. The proportional prevalence of $\mathrm{T}$. congolense is significantly higher $(\mathrm{P}=0.000)$ than the other trypanosome species. The mean $\mathrm{PCV}$ values recorded were $21.52 \%$ in parasitaemic and $28.49 \%$ in aparasitaemic animals with a statistical significant difference $(\mathrm{P}<0.05)$. About 40 traps were deployed for 48 hours $(2$ days $)$ for collection of tsetse fly. A total of 557 flies were collected from a study area, of which the higher density was for tsetse fly 382 (4.90 flies per trap per day) followed by 137 Stomoxys, 32 Tabanus and 6 haematopta. Generally, this study showed that trypanosomosis is still present and becomes a constraint for livestock production of the study area. So control and prevention mechanisms must be continued to reduce prevalence of the disease and tsetse flies population.
\end{abstract}

Keywords: Trypanosomes, Tsetse Flies, Bovine, Didesa and Pcv

\section{Introduction}

Ethiopia has enormous livestock resource with a total contribution of $15 \%$ to gross domestic product (GDP) and $33 \%$ to agricultural output. Current estimates of livestock population show that there are 41.5 million heads of cattle, 41 million sheep and goats, 5.8 million equines, 1 million camels, and over 52 million poultry (DACA, 2006).Despite the importance of livestock to the larger sector of the population and to the economy at large, the sub-sector has remained untapped. The little benefit from the enormous livestock resource of the country is attributable to a multitude of problems. This comprises of diseases, age-old traditional management system, inferior genetic make-up coupled with under nutrition and complicated by malnutrition and absence of well-developed market infrastructure (MoARD,
1997).While tsetse- borne trypanosomosis is excluding some 180,000 to $200,000 \mathrm{~km} 2$ of agriculturally suitable landing the west and south west of the country, 14 million heads of cattle, an equivalent number of small ruminants, nearly 7 million equines and 1.8 million camels are at risk of contracting trypanosomosis at any one time (MoARD, 2004).

Trypanosomosis is a complex disease caused by unicellular parasites (trypanosomes) found in the blood and other tissues of vertebrates including cattle and man (Tesfaye, 2002; Uilenberg, 1998). It is flagellated protozoa, which are transmitted by a number of different arthropod vectors but mainly by biting flies (Urquhart et al., 1996). The most important trypanosome species affecting livestock in Ethiopia are Trypanosoma congolense, Trypanosoma vivax 
and Trypanosoma brucei, in cattle, sheep and goats, Trypanosoma evansi in camels and Trypanosoma equiperdium in horses (Getachew, 2005).

Trypanosomosis is a major constraint contributing to the direct and indirect economic losses to crop and livestock production (Abebe, 2005). Trypanosomosis in Africa costs livestock producers and consumers an estimated US \$ 1 billion each year (kristajonson et. al., 1999). It is a severe problem to agricultural production in widespread areas of the tsetse infested regions (Slingenbergh, 1992) that accounts over 10 million square kilometers of the tropical Africa (Budd, 1999). In Ethiopia, Trypanosomosis is widespread in domestic livestock in the Western, South and South-western lowland regions and the associated river systems (i.e. Abay, Ghibe Omo and Baro/Akobo) (Abebe and Jobre, 1996; Abebe, 2005; Langridge,). Currently about 220,000 Km2 areas of the above mentioned regions are infested with five species of tsetse flies namely Glossinapallidipes, G .morsitans, G. fuscipes, G. tachinoides and G. longipennis (NTTIC, 2004).

Recent findings indicate that the potential area of tsetse infestation is estimated to be ranging from 135,000-220,000 square kilometres based on maximum dispersals up to 2000 meters above sea level (Slingenbergh, 1992). Economically the tsetse-transmitted trypanosomes (Trypanosoma congolense, T. vivax, and T. brucei) are most important in cattle with 14 million heads at risk in Ethiopia (Abebe, 2005; Upadhayaya, 2005). Past activities of tsetse and trypanosomosis control measures were initiated from early 1960s by French veterinary Assistance Mission followed by British Veterinary Assistance Mission up to 1976. The National Tsetse and Trypanosomosis Investigation and Control Centre (NTTICC) was established in 1971 to run activities on tsetse and trypanosomosis control (Lemecha, 1994). Since then different tsetse control projects were underway by NTTICC and thus meaningful achievements were recorded as some areas were freed of tsetse. These tsetse control activities against, mainly, Glossina morsitans submorsitans were undertaken in an area of over $4500 \mathrm{~km} 2$ of Didessa Valley as part of the Eastern Africa Regional Program.

However, only limited works were done on the prevalence of diseases, species of causative agents and vectors involved in Dideasa district as this information is important in preventing disease and reinvasion of the freed sites. This necessitates a continued follow-up and evaluation of the current status of tsetse infestation and occurrence of trypanosomosis in such controlled sites and their surrounding villages. Therefore, the present study was aimed at determining the status of the diseases and vectors with the following specific objectives:

Specific objectives:

- To investigate the status of bovine trypanosomosis and species identification

- To identify the tsetse species and density in the study area

\section{Materials and Methods}

\subsection{Study Area Description}

Didessa woreda is found in Illu Ababor zone of Oromiya region $430 \mathrm{~km}$ from Addis Ababa to western Ethiopia. The total area coverage of the district is 72,848 hector of which $10,970.75$ hector is covered by forest, 10,466 hector is grazing land and $9,920.88$ hector is cultivating land. The mean annual rainfall is $900-1000 \mathrm{~mm}$ and the mean daily temperature is $12-18^{\circ} \mathrm{c}$. The animals that found in the woreda are 107,526 bovine, 26,380 ovine, 9355 caprine, 19804 equines and 54750 poultry. The main crops cultivated in the area are maize, teff, sourghum, and barley (Didesa animal agency, 2012).

\subsection{Study Design and Sampling Methods}

A cross-sectional study design was used to determine current prevalence of bovine trypanosomosis in the study area from November 2013 to June 2014. The study district and peasant association was purposively selected. Study animals were selected with a simple random sampling. Desired sampling size was calculated according to the formula given by (Thrusfield, 2005). But to improve the degree of precision a total of 556 samples were taken for the present study.

\subsection{Study Animals and Blood Sampling}

Animals used in this study were local zebu cattle (Bos indicus), which are usually kept under an extensive husbandry system. Animals were allowed to graze freely during the day and housed in poorly constructed barns at night. Blood sample was taken from the randomly selected cattle. During sampling PAs, age, sex and body condition score of animals were recorded. The age was categorized in to three (0-2 years, 3-5 years and greater than five years). Body condition score was grouped in to poor and good conditioned animals based on the appearance of ribs and dorsal spines applied for Zebu cattle (Nicholson and Butterworth, 1986).

\subsection{Parasitological Study}

A total of 556 cattle were examined for blood sample collection. Blood sample was collected by puncturing of the marginal ear vein of each animal with a lancet and drawn directly into heparinized capillary tube and centrifuged with capillary hematocrit centrifuge (Woo, 1970). PCV measurement of trypanosomes was done by the dark ground Buffy coat technique (Murray et al., 1984). Positive samples were further processed for thin blood smear for confirmation of trypanosome species using their morphological characteristics (Paris et al.,1982) with Giemsa staining techniques.

\subsection{Entomological Survey}

The apparent densities of tsetse and biting flies were 
determined based on the mean fly catches in traps baited with acetone, octenol and cow's urine. A total of 40 traps with a monoconical shape were placed approximately $100 \mathrm{~m}$ apart and left in position for two consecutive days (48 hrs).The flies caught per trap were identified, counted and apparent fly density per trap per day $(\mathrm{f} / \mathrm{t} / \mathrm{d})$ was recorded. The tsetse flies were identified to species level (Marquardt et al. 2000).

\subsection{Data Analysis}

Collected data was fed to Microsoft Excel spread sheet and process of coding, handling and validating was done on this sheet. Coded was transferred to SPSS version 20.0 for analysis. Descriptive statistics, student t-test and chi-square tests were used to express results and analysis of variables. The trypanosomosis with variables; peasants association, age, sex and body condition score was compared by chi-square test. The mean PCV of infected and non-infected animals were compared with student t-test.

\section{Results}

\subsection{Parasitological Findings}

The overall prevalence of trypanosomosis was $4.86 \%$ in Didessa district in the study period as shown in Table- 1 . The prevalence of trypanosome species in cattle within peasant association in the study areas were $5.43 \%, 4.87 \%, 5.4 \%$ and $3.93 \%$ in Busi, Doyo, Dingo and Hunqe respectively. There was no statistical significant difference between PAs $(\mathrm{P}>0.05)$. The prevalence of trypanosomes infection differed between age categories 0-2 years, 3-5 years and greater than 5 years but not significant $(\mathrm{P}>0.05)$. Higher prevalence observed $6.1 \%$ in age group $<2$ years compared to the $3-5$ years age category (4.1). The prevalence of trypanosome infection was slightly higher in male $5.6 \%$ than female $4.32 \%$ animals but there was no statistically significant difference $(\mathrm{p}>0.05)$. The prevalence trypanosomes in body condition score shows no significant association but high prevalence found in poor $(7.94 \%)$ followed by medium (4.32) and lowest in good $(2.53 \%)$ as indicated in Table-2.

Table 1. Prevalence of Trypanosomosis in Study area of PA's.

\begin{tabular}{llllll}
\hline PA's & $\begin{array}{l}\text { No. of animal } \\
\text { examined }\end{array}$ & $\begin{array}{l}\text { No. } \\
\text { positive }\end{array}$ & Prevalence & $\mathbf{X}^{\mathbf{2}}$ & p-value \\
\hline Busi & 92 & 5 & 5.43 & & \\
Dingo & 164 & 8 & 4.84 & 0.44 & 0.93 \\
Doyo & 148 & 8 & 5.4 & & \\
Hunqe & 152 & 6 & 3.94 & & \\
Total & 556 & 27 & 4.86 & & \\
\hline
\end{tabular}

Table 2. Prevalence of Trypanosomosis between Sex, age group and body condition score.

\begin{tabular}{llll|l|l}
\hline Factors & $\begin{array}{l}\text { No. of animals } \\
\text { examined }\end{array}$ & $\begin{array}{l}\text { No. of } \\
\text { positive }\end{array}$ & $\begin{array}{l}\text { Prevalence } \\
(\mathbf{\%})\end{array}$ & $\mathbf{X}^{\mathbf{2}}$ & $\begin{array}{l}\text { p- } \\
\text { value }\end{array}$ \\
\hline Sex & & & & & \\
Female & 324 & 14 & 4.32 & 0.49 & 0.488 \\
Male & 232 & 13 & 5.60 & & \\
Age & & & & & \\
$1-2$ & 82 & 5 & 6.1 & 0.495 & 0.71 \\
$3-5$ & 171 & 7 & 4.1 & & \\
$>5$ & 303 & 15 & 4.9 & & \\
BCS & & 10 & 7.94 & & \\
Poor & 126 & 15 & 4.32 & 3.77 & 0.15 \\
Medium & 351 & 2 & 2.53 & & \\
\hline Good & 79 & 10 & & & \\
\hline
\end{tabular}

\subsection{Hematological Findings}

The proportion of trypanosome infection with species level indicated that $17(62.96 \%)$ cattle were found to be infected by T. congolense, $9(33.33 \%)$ cattle were found to be infected by T. vivax and 1 (3.70) cattle were found to be infected by mixed (TC \& TV) as shown in Table-4. PCV of individual animals was measured for the assessment of degree of anemia. A mean PCV of $21.52 \%$ and $28.75 \%$ were found for infected animals and non infected animals respectively as indicated in Table-3. The difference was statistically significant $(\mathrm{P}=0.000)$.

Table 3. Mean PCV in Parasitemic and aparasitemic cattle.

\begin{tabular}{lllll}
\hline Condition & Mean PCV\% & $\mathbf{9 5 \%}$ CI & Std error & p-value \\
\hline Infected & 21.52 & $21.04-22.00$ & 0.24 & 0.000 \\
Non infected & 28.75 & $28.50-29.03$ & 0.14 & \\
\hline
\end{tabular}

Table 4. Ratio of trypanosome species infection.

\begin{tabular}{l|l|l|l|l}
\hline T. species & $\begin{array}{l}\text { No. of } \\
\text { positive }\end{array}$ & Percentage (\%) & $\mathbf{X}^{2}$ & p-value \\
\hline T. congolence & 17 & 62.96 & & \\
T. vivax & 9 & 33.33 & 54.00 & 0.00 \\
TC \$ TV mixed & 1 & 3.71 & & \\
Total & 27 & 100.00 & & \\
\hline
\end{tabular}

\subsection{Entomological Findings}

A total of 577 flies were caught. Of these, 392 belong to Glossina species, 147 were Stomoxys, 32 were Tabanus and 6 were heamotopota. Furthermore, all Glossina species caught were Glossina tachinoides. The overall apparent fly density was $3.56 \mathrm{f} / \mathrm{t} / \mathrm{d}$ as it is put in Table-5.

Table 5. Flies FTD between PA's.

\begin{tabular}{|c|c|c|c|c|c|c|c|c|c|c|}
\hline \multirow{2}{*}{ PA's } & \multirow{2}{*}{$\begin{array}{l}\text { No.of } \\
\text { trap }\end{array}$} & \multicolumn{2}{|c|}{ Glossina species } & \multicolumn{5}{|c|}{ Other biting flies } & \multirow{2}{*}{$\begin{array}{l}\text { Over all } \\
\text { total }\end{array}$} & \multirow{2}{*}{$\begin{array}{l}\text { Over all } \\
\text { FTD }\end{array}$} \\
\hline & & Tach. & FTD & Tab & Stom & Heam & total & FTD & & \\
\hline Busi & 10 & 88 & 4.4 & 00 & 13 & 1 & 14 & 0.7 & \multirow{4}{*}{577} & \multirow{4}{*}{3.56} \\
\hline Dingo & 10 & 20 & 1 & 1 & 46 & 4 & 51 & 2.56 & & \\
\hline Doyo & 10 & 131 & 6.55 & 19 & 65 & 1 & 85 & 4.25 & & \\
\hline Hunqe & 10 & 153 & 7.65 & 12 & 23 & 00 & 35 & 1.66 & & \\
\hline
\end{tabular}




\section{Discussion}

The present study revealed that from a total of 556 randomly selected cattle's in the study area, 27 (4.86\%) of animals were positive for trypanosomes. Similar findings of 4.43\% from Arbaminch (Teka et al., 2012) were reported. But this is lower than previous reports: $12.41 \%$ in Metekel and Awi zones of northwest Ethiopia (Solomon \& Fitta, 2010) and $20.40 \%$ in Wolyta and Dawero zones of southern Ethiopia Miruk et al., 2008. The relatively low prevalence of trypanosomosis in this study may be related to tsetse distribution and low fly-animal contact and parasite and vector control programmes practiced in the area by Bedele NTTICC annually. In Didesa woreda every farmer in tsetse belt area has trypanocidal drugs in his home that he injects his cattle by non professional individuals.

In another way low sensitivity of direct parasitological Buffy coat examination may contribute for low prevalence that chronic stage is characterized by low parasitemic which is difficult to confirm by parasitological diagnosis (Simukoko, 2011). In very low sensitivity of Buffy coat method $50 \%$ of infected animals remained undetected using parasitological diagnostic tools as compared to the molecular analysis animals (Simukoko, 2011). In this study the prevalence of bovine trypanosomosis between peasant associations was not significant; even though it is higher than others in in busi (5.43). This may be the result of uncontrolled animal movements between PA's by buying and selling cattles between the PA's.

The animals examined were categorized in 3 age groups; 1-2(young) age, 3-5 age, and $>5$ years old. The trypanosome infection prevalence was found to be $6.1 \%$ in the $1-2$ age group, 4.1 in 3-5 age group and $4.9 \%$ in above 5 years old animals as indicated in table-2. Even though prevalence in young animals was not with higher significant variation, this might be because of an equal chance of exposure to parasites. Similar findings were also reported by Cheren et al. (2006) and Habtamu (2009) in the Jawi district of the Amhara region, Ethiopia. During the study period, the prevalence of bovine trypanosomosis was assessed between sexes of animals and there is no significant difference. Among 27 trypanosome positive animals; $14(4.32 \%)$ of them were female animals and $13(5.6 .52 \%)$ of them were male animals. Even though the trypanosome infection in male animals is slightly higher than in the female animals; both sexes were equally susceptible to trypanosomosis infection. This result is similar with previous results of (Teka et al., 2012) and Daya and Abebe (2008) who obtained no significant difference in susceptibility between the two sexes.

The occurrence of disease in three different body condition (poor, good and medium) animals shows the highest prevalence in poor body condition (7.94\%) followed by in medium $(4.32 \%)$ and good body condition $(2.53 \%)$. This finding is consistent with the observations of Tadesse and Tsegaye (2010) and Bitew et al. (2011). In contrast, $21.93 \%$ aparasitaemic cattle were with poor body condition and this indicates that other factors such as diseases, nutritional factors as well as management system may have contributed for the poor body condition of cattle (Smith, 2009).The absence of trypanosome infection in the poor body condition animals might be due to malnourishment, internal parasites and other body loss causing diseases (OIE, 2009).

In this study, there was a significant difference between mean PCV values of infected and non-infected animals. This factor may be related to the debilitating nature of the disease (Radostits et al., 2007). In the absence of other diseases causing anemia, a low PCV value of individual animals is a good indicator of trypanosome infection (Abebe, 2005; Marcotty et al., 2008). During the study period, cattle with $\mathrm{PCV} \leq 24 \%$ were considered anemic (Van den Bossche et al., 2001) which is said to be the principal sign of trypanosomosis in livestock (Gardiner, 1989). In the present study, the mean PCV value for the parasitemic cattle was $21.52 \%$ while the mean PCV value for the aparasitaemic cattle was $28.75 \%$; which is similar with the report of (Rowlands et al., 1993) in Ghibe valley at South Western Ethiopia, in which was stated that the average PCV of parasitological negative animals was significantly higher than the average PCV of parasitological positive animals.

From the total cattle populations sampled during study period, $19.42 \%$ of cattle populations have $\mathrm{PCV} \leq 24 \%$, but some of them react negatively for trypanosomosis infection and this may have occurred due to the inadequacy of detection method used or delayed recovery of anemic situations after recent treatment with trypanocidal drugs or may be due to the compound effect of poor nutrition and hematophagous helminthes infection such as haemonchosis and bunostomiasis (Afework, 1998). The present study also revealed that almost $2.23 \%$ of the cattle have a $\mathrm{PCV}$ value in the normal range $(\mathrm{PCV}>24 \%)$ but they react positively to trypanosomosis infection and this may have occurred due to recent infection with trypanosomosis. This result agree with the previous result of (Garoma, 2009) who conclude that cattle's having PCV value of normal range were shown to be infected with trypanosome parasite.

Morphological identification of the species of trypanosomes involved in the study area was T.vivax and T. congolense. In the present study the prevalence of $\mathrm{T}$. congolense was $(62.96 \%)$ higher than the prevalence of $\mathrm{T}$. vivax $(33.33 \%)$ and TC \& TV mixed infection (3.70). The high proportion of $\mathrm{T}$. congolense detected in this study agreed with the report of Abebe (2007) which is 58\% due to $\mathrm{T}$. congolense. Such a high ratio of $\mathrm{T}$. congolense may be caused by the presence of a biological vector (Glossina), whereas $T$. vivax is more readily transmitted mechanically by biting flies than tsetse flies(Langridge, 1976) and $\mathrm{T}$. congolense is mainly confirmed in the blood, while T. vivax and T. brucei also invade the tissues (Hoare, 1972;). Other studies by Rowlands et al. (1995), Leak et al. (1999) have indicated that T.vivax is highly susceptible to treatment while the problems of drug resistance are higher in $\mathrm{T}$. 
congolense.

The density of tsetse population in the study area, and the level of their contact with the host, can be determined by the level of infection (Radostits et al., 2007). The average tsetse fly density in the area was $382(4.91 \mathrm{~F} / \mathrm{T} / \mathrm{D})$ and over all density of all flies are (3.56 F/T/D). This finding seems to be slightly lower than the previous report $11.2 \mathrm{~F} / \mathrm{T} / \mathrm{D}$ by SRVL (2006) in daremello district. Concerning tsetse fly species only Glossina tachnoides were observed and among mechanical transmitters of trypanosomosis found in the study area were Tabanus, stomoxy and haematopta.

\section{Conclusions and Recommendations}

Our study results revealed that bovine trypanosomosis and apparent tsetse density survey in four villages of Didesa Woreda indicated that an overall $4.86 \%$ prevalence of the disease and density of tsetse flies with an overall apparent density of 3.56flies/trap/day. In this study T. vivax (33.33\%) and T. congolense $(62.96 \%)$ are trypanosome species identified and on entomological survey, only one species of tsetse fly identified was G. tachinoides. Higher prevalence of trypanosomosis infection was observed in animals with poor body condition and low Pcv animals. From the total risk factors only pcv found significant and others are in significant.

Based on the conclusion, the following recommendations are forwarded:

- Strategic control of bovine trypanosomosis including vector control should be strengthened to improve livestock production and agricultural development in the area.

- Attempt should be made to expand government and private veterinary services to serve the community in the study areas.

- Further surveys and studies should be conducted and appropriate, feasible control of trypanosomosis must be done.

- Educating the public in the tse tse belt or affected areas of trypanosome to participate $t$ in control strategies.

\section{References}

[1] Abebe, G., and Jobre, Y., (1996): Trypanosomosis. A threat to cattle production in Ethiopia.Rev.Med. Vet.147: 897-902.

[2] Abebe, G., 2005: 'Trypanosomosis in Ethiopia', Ethiopian Journal of Biological Science 4:1, 75-123.

[3] Abebe, G., Malone, J. B. and Thompson, A. R. (2004): Geospatial forecast model for tsetse transmitted animal trypanosomosis in Ethiopia. SINET, Ethio. J .sci. 27(1): 1-8.

[4] Adam, K. M. G., Paul, J. and Zaman, V. (1979): Medical and Veterinary Protozology. An Illustrated Guide. Churchill Livingstone. Edinburgh and London.

[5] Afework, Y. (1998). Field inestigations on the appearance of drug resistant population of trypanosome.
[6] Bitew, M., Amedie, Y. and Abebe, A, (2011): Prevalence of bovine trypanosomosis in selected areas of Jabi Tehenan district, West Gojam of Amhara regional state, North western Ethiopia. Global Veterinaria, 5: 243-247.

[7] Blood, D.C., Radostits, O.M. and Henderson, J.A., (1989): Disease caused by protozoa. A text book of the disease of cattle, pigs, goats and horses. 7th ed. Oxford: ELBS, PP: 1012- 1015.

[8] Bourn, D., Reid, R., Rogers, D., Snow, W. and Wint, W. (2001): Environmental change and the autonomous control of tsetse and trypanosomosis in sub-Saharan Africa. Environmental Research Group Oxford, Oxford, UK. PP: 248.

[9] Brightwell, R., Dransfield, R. D., Maudlin, I., Stevenson, P. and Shaw, A. (2001): Reality vs rhetoric - a survey and evaluation of tsetse control in East Kenya. Agric Human Values, 18:19-233.

[10] Budd, L. T. (1999): DFID-funded tsetse and trypanosomiasis research and development since 1980. Vol. 2 Economic Analysis. Department for International Development (DFID), London, UK.

[11] Cherenet, T., Sani, R.A., Speybroeck, N., Panandam, J.M., Nadzr, S. \& Van den Bossche, P., 2006, 'A comparative longitudinal study of bovine trypanosomiasis in tsetse-free and tsetse-infested zones of the Amhara region, northwest Ethiopia', Veterinary Parasitology 140:251-258.

[12] Codjia, V., Mulatu, W., Majiwa, P. A. O., d'Ieteren, G. D. M. and Peregrine, A. S. (1993):Epidemiology of bovine trypanosomosis in the Ghibe valley, southwest Ethiopia. Occurrence of population of Trypanosoma congolense resistant to diminazine, isometamidium andhomidium. Acta Trop. 53: 151-163.

[13] DACA (2006): standard veterinary Treatment Guidelines for veterinary practice 1 Sted. Drug Administration and Control Authority of Ethiopia.

[14] Dagnachew. S and Abebe. G., 2007. Studies on tsetsetransmitted trypanosomosis in new settlementareas of Jawi and Quara districts of Amhara region northwest Ethiopia. In proceedings ofthe 29th meeting of the International Scientific Councilfor Trypanosomosis Research and Control (ISCTRC), Luanda, Angola, 1st -5thOctober 2007.

[15] Dagnachew, S., Sangwan, A. K., Abebe, G. (2005): Epidemiology of Bovine Trypanosomosis in the Abay (Blue Nile) Basine Areas of North West Ethiopia. Revue. Elevl. Med. Vet .Pays trop.

[16] Daya, T. and Abebe, G. (2008): Seasonal Dynamics of Tsetse and Trypanosomosis in selected sites of Southern Nation, Nationalities and Peoples regional State, Ethiopia. Ethiop.Vet J.,12(2): 77-92.

[17] De La Rocque, S., Michel, J. F., Michel, V. and Cuisance, D. (2001b): Trypanosomosis epidemiology and control in West Africa: Epidemiological diversity of trypanosomosis at a local level. Newsl Integr Control Pathogenic Trypanosomes Vectors, 3:7-9.

[18] Erkelens, A. M., Dwinger, R. D., Bedane, B., Slingenbergh, J. H. W., Wint, W. (2000): Selection of priority areas for tsetse control in Africa: a decision tool using GIS in Didessa valley, Ethiopia, as a pilot study. In: Animal Trypanosomosis: Diagnosis and Epidemiology. ISBN90-5782-065-x. International Atomic Energy Agency. Vienna, Austria, PP: 213-227. 
[19] Eth. Ministry of Agriculture and Rural Development of the Government of Ethiopia (MoARD) (2004).Tsetse and trypanosomiasis prevention and control strategies. Amharic Version. October 2004 (Tikimt, 1997. Cal). Paper presented on Farming Tsetse Controlled Areas (FITCA), Ethiopia. Final Work Shop, December, 27- 28, 2004. Adama, Ethiopia.

[20] FAO (1998): A field guide for the diagnosis, treatment and prevention of African Animal Trypanosomiasis. Rome, Italy. Pp: 12-135.

[21] FAO (2001): Integrating the sterile insect technique as a component of area wide tsetse and trypanosomosis intervention. PAAT, Technical and scientific series by Feldman. U, and Hendricks, J. FAO, Rome, PP: 56-68.

[22] Feldmann, U. and Hendrichs, J. (2001): Integrating the sterile insect technique as a key component of area wide tsetse and trypanosomosis investigation. Vienna, Austria, 10: 42-56.

[23] Ford, J., Makin, M.J. and Grimble, R.J. 1976. Trypanosomiasis control programme for Ethiopia, Ministry of Overseas Development, London, 12-29.

[24] Gardiner, N. (1989). Recent study on the biology of T. vivax. Adv. Parasitol., 28: 230- 279.

[25] Garoma, D. (2009). The prevalence of bovine trypanosomosis in Gari settlement area of East Wollega Zone. DVM Thesis Jimma University, FVM, Jimma, Ethiopia.

[26] Getachew, A. (2005): Trypanosomosis in Ethiopia, Addis Ababa University, faculty of Veterinary Medicine. Debre Zeit, Ethiopia. J .Biol.sci.4(1):18-21; 75-121.

[27] Gooding, R. H. \& Krafsur, and E. S., (2005): Tsetse genetics: Contributions to biology, systematic, and control of tsetse flies Annual Review of Entomology, 50: 101 - 123.

[28] Habtamu, G. (2009), 'Current status of tsetse transmitted trypanosomes in Jawi district of Amhara region, north-west Ethiopia', DVM thesis, Faculty of Veterinary Medicine, Gondar University. Leak, S.G., 1996, 'The contribution to the epidemiology and understanding tsetse transmitted trypanosomiasis', PhD thesis, Universiteit Utrecht.

[29] Hoare, C. A. (1972): The trypanosomes of mammals, Oxford: Blackwell scientific publications. Pp: 749.

[30] Itard, J. (1989): African Animal Trypanosomioses. In: Manual of Tropical Veterinary Parasitology. 1st English edition. Published by C.A.B.I. UK, PP: 179-181.

[31] Jordan, A. M. (1993): Tsetse flies (Glossinidae). Medical Insects and Arachnids (ed. by R. P. Lane \& R. W. Crosskey) Chapman \& Hall, London, PP: 333 - 388.

[32] Kristjanson, P. M., Swallow, B.M., Rowlands, G. J., Krusska, R. L. and Leeuw, D., (1999): measuring the cost of African animal trypanosomosis, the potential benefit of control and returns to research. Agr. Sys., 59:79-98.

[33] Langridge, P. W. (1976): A Tsetse and Trypanosomosis Survey of Ethiopia. Ministry of Overseas Development (UK) and Ministry of Agriculture of the Ethiopia. PP: 1-40.

[34] Leak, S. D., (1999): Tsetse Biology and Ecology.The role in the Epidemiology and controlof trypanosomosis. $\mathrm{CAB}$ international. Wallingford (UK), PP: 21-26; 152-210.

[35] Leak, S. G. A. and Mulatu, W., 1993.Advance of Glossina morsitans submorsitans and G. pallidipes along the Ghibe river system in south west Ethiopia. Act Trop., 55:91-95.
[36] Lemecha, H. (1994): Trypanosomosis Research and Control in Ethiopia. An Overview. Proceedings of 8th Annual Conference of the Ethiopian Veterinary Association, Addis Ababa, Ethiopia. PP: 7-12.

[37] Losos, J. E. (1986): Infectious of Tropical Disease of Domestic Animals. Pp:186.

[38] Majiwa, P. A. O., Masake, R. A., Nantulya, V. M., Hamers, R. and Matthyssens, G. (1985): Trypanosoma (Nannomonas) congolense: identification of two karyotypic groups. European Molecular Biology Organization Journal4:3307-3313.

[39] Marcotty, T., Simukoko, H., Berkvens, D., Vercruysse, J., Praet, N. \& Van Den Bossche, P., 2008, 'Evaluating the use of packed cell volume as an indicator of trypanosomal infections in cattle in eastern Zambia', Preventive Veterinary Medicine $87,288-300$.

[40] Marquardt, W.C., Demaree, R.C. \& Grieue, R.B., 2000, Parasitology and vector biology, 2nd edn., Academic Press, London.

[41] Maudlin, I.A., Holmer, P.H. \& Milor, M.A., 2004, The typanosomosis, Centre for Agricultural Bioscience International, Egham.

[42] Ministry of Agriculture and Rural Development of the Government of Ethiopia (MoARD) (2004): Tsetse and trypanosomosis prevention and control strategies. Amharic version, Paper presented on Farming Tsetse Controlled Areas, Ethiopia. Final workshop, December, 27-28, 2004. Adama, Ethiopia. Unpublished workshop proceeding.

[43] Miruk, A., Hagos, A., Yacob, H.T., Asnake, F. \& Basu, A.K., 2008, 'Prevalence of bovine trypanosomosis and trypanocidal drug sensitivity studies on Trypanosoma congolense in Wolyta and Dawero zones of southern Ethiopia', Veterinary Parasitology 152, 141-147.

[44] MoA (Ministry of Agricultural), 1995.Ethiopian ruminant livestock developmentstrategy. Addis Ababa, Ethiopia, Ministry of Agricultural, p.112-113.

[45] MoA (Ministry of Agricultural), 1997.Livestock development policies in Eastern and Southern Africa. Proceedings of a seminar organized by CTA, OAU/IBAR and the Ministry of Agriculture and Cooperatives, Swaziland, 28 July-1 August. pp.216.

[46] Morrison, W. L., Murray, M., and Mcintyre, W. I. M., (1981): Bovin trypanosmiasis in Diseses of Cattle in the Tropics. M. Ristic and I. McIntyre (Ed) Martinus Nyhoff Publishers, the Hague, PP: 469-497.

[47] Mulligan, H. W. (1970): The African Trypanosomiases. George Allen and Unwin Ltd. London. PP: 950.

[48] Murray, M. and Gray, A. R. (1984): Current situation in Animal Trypanosomiasis in Africa. In Riemann, HP. and Burridge, M. J. (ed) Impact of Diseases on Livestock Production in the Tropics. Elsevier Science Publishing Co. Inc., New York, USA.

[49] Muturi KS. (1999:.Epidemiology of bovine Trypanosomosis in selected sites of the Southern rift valley of Ethiopia.MSc thesis, Addis Ababa University with Freie University, Berlin.

[50] Nicholson, M.J. \& Butterworth, M.H., 1986, A guide to scoring of zebu cattle, International Livestock Centre for Africa, Addis Ababa. 
[51] NTTICC (National Tsetse and Trypanosomiasis Investigation and Control Centre) Annual Report on Tsetse and Trypanosomosis Survey, 2004. Bedelle, Ethiopia.

[52] OIE (2005): Animal Disease Factsheets, The center for Food Security and Public Health Iowa State, state University, Ames, IA. USA.

[53] OIE, (2004): Tsetse transmitted trypanosomosis. In: Manual of diagnostic tests and vaccines for terresterial animals. World Organization for Animal Health. 5th Ed. Pp: 235-345.

[54] Oloo, F. P., Langley, P.A., Luyimbazi, F., and Ogwal, L. M. (2000): Integration of the sterile insect technique (SIT) and auto sterilization let halite in the eradication of Glossina fuscipes Newst. (Diptera, Glossinida) in Buudma ISL and in Lake Victoria, Uganda. Pp: 311-314.

[55] Paris, J., M. Murray and F. Mcodimba, (1982): A comparative evaluation of the parasitological technique currently available for the diagnosis of African Trypanosomosis in Cattle, Acta Trop, 39: 1-11.

[56] PATTEC (2001): Pan Africa Tsetse and Trypanosomosis Eradication Campaign (PATTEC). Plan of action. June, 2001.

[57] Peregrine, A. S. (1994): Chemotherapy and delivery systems: haemoparasites. Vet Parasitol, 54: 223- 248.

[58] Radostits, O. M, Gay, C., Blood, D. C, Hinchclift, K. W. (2007): Veterinary Medicine, a Text Book of the Diseases of Cattle, Sheep, Goats, Pigs and Horses. 10th ed., London, Harcourt Publishers' Ltd. Pp: 1564-1569.

[59] Radostits, O. M., Gay, C. C, Blood, D. C,and Hinchcliff, W. K (2000): Veterinary Medicine. A textbook of the disease of cattle, sheep, pigs, goats and horse, 9th ed. W.B. Saunders. Sankatoon, Canada. PP: 1329-1334; 1531-1548.

[60] Robertson, H. (2004): Family Glossinidae (tsetse flies). Biodiversity explorer. Iziko, Museume of Cape Town, South Africa. 82: 95-97.

[61] Rowlands, G. J., Mulatu, W., Authie, E., D' ieteren, G. D. M., Leak, S. G. A., Nagda, S. M, and Pregrine, A. S. (1993): Epidemiology of bovine trypanosomosis in the Ghibe Valley, South- West Ethiopia. Acta.Trop., 53: 135- 150.

[62] Rowlands, G. S., W. Mulatu, E. Authie, S.G.A. Leak and A. Peregrine, (1995): Epidemiology of bovineTrypanosomosis in the Ghibe valley, South West Ethiopia. Acta Tropica, 53: 135150 .

[63] Seifert, H. S. H. (1996): Tropical Animal Health. Kluwer Academic Publishers. The Netherlands 2nded. Pp:152-169.

[64] Shereni, W. (1990): Strategic and tactical development in tstse control in Zinbabuwe. Insect. Sci. Applic., 11: 399-409.

[65] Simukoko, H., T. Marcotty, J. Vercruysse andP. Van den Bossche, 2011. Bovine trypanosomiasis risk in an endemic area on the eastern plateau of Zambia. Research in Veterinary Science, 90: 51-54.

[66] Slingenbergh, J. H. W. (1992): Consolidation of tsetse and trypanosomosis control in the upper Didessa valley. Consultancy report of the tsetse control specialist to the Fourth Livestock Development Project,FAO, and Rome. pp.255.

[67] Smith B P(2009) Trypanosomosis. In: Large Animal Internal Medicine. 4th edn, pp 1160.
[68] Solomon, M. \& Fitta, G., 2010, 'Survey on bovine trypanosomosis and its vector in Metekel and Awi zones of northwest Ethiopia', Acta Tropica 117(2011), 146-151.

[69] Soulsby, E. J. (1982): Helminthes, Arthropods, and protozoa of domestic animals 7th edition clows ltd. Beacles and London. Pp: 523-530.

[70] SRVL (2006). Sodo Regional Veterinary Laboratory report.

[71] Stephen, E. L. (1986): Trypanosomiasis. A veterinary perspective.Pergamon Press, Oxford, UK. Pp: 551.

[72] Tadesse A, Tsegaye B (2010). Bovine trypanosomosis and its vectors in two districts of Bench Maji zone, South Western Ethiopia. Trop Anim Health Prod., 42:1757-1762.

[73] Taylor, K. \& Authie, M-L. (2004): Pathogenesis of animal trypanosomiasis, in the trypanosomoses, edited by I. Maudlin, P.H. Holmes \& M.A. Miles. Oxfordshire: CABI Publishing. Pp: 331-353.

[74] Teka W., Terefe D. and Wondimu, A. (2012): Prevalence study of bovine trypanosomosis and tsetse density in selected villages of Arbaminch, Ethiopia.Journal of Veterinary Medicine and Animal Health, 4(3): PP: 36-41.

[75] Tesfaye, M. (2002): Report of trypanosome infection rate, in G.m submoristans and G.tachnoides in Didessa valley from July 29 to September 26, 2002. Bedele, Ethiopia.

[76] Thomas, C., Getachew, A., R. S. san, J. M. Panasam, S. Nadzr and P. Van Den Bosche (2005): A longitudinal study of bovine trypanosomosis in a tsetse free and tsetse infested zone of the Amhara region, North West Ethiopia. EVA. Journal. Pp: 64-74.

[77] Thrusfield, M. V., (2005): Veterinary Epidemiology. 3rd edition, Blackwell Publishing, Garsington road, Oxford, UK, PP: 233-250.

[78] Uilenberg, G. (1998): A field guide for the diagnosis, treatment and prevention of african animal trypanosomosis. Food and Agriculture Organisation of the United Nations (FAO), Rome, Italy. PP: 87-98.

[79] Upadhyaya, A., (2005) Text of preventive Veterinary Medicine 1sted., International book distributing co.( publishing Division), Army printing press ,33 Nuhru Road, saddart contt. Lucknow-226002.

[80] Urquhart, GM, Armour J, Duncan JL, Dunn AM, Jennings FW (1996). Veterinary parasitology 2nd edition.Black Well Science Ltd., London UK, pp. 212-219.:384-386.

[81] Vale, G. A. (1993): Development of baits for tsetse flies (Diptera, Glossinidae) in Zimbabuwe. J. Med. Entomol., 30: 831-842.

[82] Van den Bossche, P. and Mudenge, D. (1999): The effect of short-interval deltamethrin applications to control tsetse on the seroprevalence of babesiosis in cattle. Trop Anim Health Prod, 31(4):215-22.

[83] Van den Bossche, P. and Rowlands, G. J. (2001): The relationship between the parasitological prevalence of trypanosome infections in cattle and helped average packed cell volume. Acta Trop., 78: 168- 170.

[84] Vreysen, M., J. (2001): Principles of area wide integrated tsetse fly control using the sterile insect technique. Med. Trop., 61: 397-411. 
[85] Whitelaw, D.D., Gardiner, P.R., Murray, M. (1988). Extravascular foci of Trypanosoma vivax in goats: the central nervous system and aqueous humor of the eye aspotential sources of relapse infections after chemotherapy. Parasitology.7: 51-61.

[86] Woo, P.T.K., 1970. Haematocrit centrifugation technique for the diagnosis of African trypanosomosis.Acta trop., 27: 384386 .
[87] World Organization for Animal Health (OIE), 2009. African Animal Trypanosomiasis Miruk, A., Hagos, A., Yacob, H.T., Asnake, F. \& Basu, A.K., 2008, 'Prevalence of bovine trypanosomosis and trypanocidal drug sensitivity studies on Trypanosoma congolense in Wolyta and Dawero zones of southern Ethiopia', Veterinary Parasitology 152, 141-147. 